\title{
Correlation between electromechanical parameters (NOGA XP) and changes of myocardial ischemia in patients with refractory angina
}

\author{
Radosław Kurzelowski ${ }^{1}$, Kamil Barański², Guido Caluori ${ }^{3,4}$, Wojciech Szot ${ }^{5}$, Krzysztof Grabowski ${ }^{6}$, \\ Aleksandra Michalewska-Włudarczyk ${ }^{1}$, Marcin Syzdół ${ }^{1}$, Wacław Kuczmik ${ }^{7}$, Anna Błach ${ }^{1}$, Beata Ochała ${ }^{1}$, \\ Damian Hudziak ${ }^{8}$, Jacek Wilczek ${ }^{9}$, Krzysztof S. Gołba9 ${ }^{9}$ Zdenek Starek ${ }^{10,11}$, Michał Tendera ${ }^{1}$, \\ Wojciech Wojakowski ${ }^{1}$, Tomasz Jadczyk ${ }^{1,10}$
}

\begin{abstract}
${ }^{1}$ Department of Cardiology and Structural Heart Disease, Medical University of Silesia, Katowice, Poland ${ }^{2}$ Department of Epidemiology, Medical University of Silesia, Katowice, Poland

${ }^{3} \mathrm{HHU}$ LIRYC, Electrophysiology and Heart Modeling Institute, Fondation Bordeaux Université, Pessac, France ${ }^{4}$ Univ. Bordeaux, INSERM, UMR 1045, Cardiothoracic Research Center of Bordeaux, Pessac, France ${ }^{5}$ Department of Nuclear Medicine, John Paul II Hospital, Jagiellonian University Medical College, Krakow, Poland ${ }^{6}$ Department of Robotics and Mechatronics, AGH University of Science and Technology, Krakow, Poland ${ }^{7}$ Department of General and Vascular Surgery, Medical University of Silesia, Katowice, Poland ${ }^{8}$ Department of Cardiac Surgery, Medical University of Silesia, Katowice, Poland ${ }^{9}$ Department of Electrocardiology and Heart Failure, Medical University of Silesia, Katowice, Poland ${ }^{10}$ Interventional Cardiac Electrophysiology Group, International Clinical Research Center, St. Anne's University Hospital, Brno, Czech Republic ${ }^{11} 1^{\text {st }}$ Department of Internal Medicine - Cardioangiology, St. Anne’s University Hospital, Brno, Czech Republic
\end{abstract}

Adv Interv Cardiol 2021; 17, 3 (65): 281-289 DOI: https://doi.org/10.5114/aic.2021.109168

\begin{abstract}
A bstract
Introduction: Cell therapy has the potential to improve symptoms and clinical outcomes in refractory angina (RFA). Further analyses are needed to evaluate factors influencing its therapeutic effectiveness.

Aim: Assessment of electromechanical (EM) parameters of the left ventricle (LV) and investigation of correlation between EM parameters of the myocardium and response to CD133+ cell therapy.

Material and methods: Thirty patients with RFA (16 active and 14 placebo individuals) enrolled in the REGENT-VSEL trial underwent EM evaluation of the LV with intracardiac mapping system. The following parameters were analyzed: unipolar voltage (UV), bipolar voltage (BV), local linear shortening (LLS). Myocardial ischemia was evaluated with single-photon emission computed tomography (SPECT). The median value of each EM parameter was used for intra-group comparisons.

Results: Global EM parameters (UV, BV, LLS) of LV in active and placebo groups were $11.28 \mathrm{mV}, 3.58 \mathrm{mV}, 11.12 \%$, respectively; $13.00 \mathrm{mV}, 3.81 \mathrm{mV}, 11.32 \%$, respectively. EM characteristics analyzed at global and segmental levels did not predict response to CD133+ cell therapy in patients with RFA (Global UV, BV and LLS at rest $R=-0.06 ; R=0.2 ; R=-0.1$ and at stress: $R=0.07, R=0.09$, $R=-0.1$, respectively; Segmental UV, BV, LLS at rest $R=-0.2, R=0.03, R=-0.4$ and at stress $R=0.02, R=0.2, R=-0.2$, respectively). Multiple linear regression of the treated segments showed that only pre-injection SPECT levels were significantly correlated with post-injection SPECT, either at rest or stress $(p<0.05)$.

Conclusions: Electromechanical characteristics of the left ventricle do not predict changes of myocardial perfusion by SPECT after cell therapy. Baseline SPECT results are only predictors of changes of myocardial ischemia observed at 4-month follow-up.
\end{abstract}

Key words: electromechanical mapping, refractory angina, CD133+, cell therapy, NOGA XP.

\section{Corresponding author:}

Tomasz Jadczyk MD, PhD, Department of Cardiology and Structural Heart Diseases, Medical University of Silesia, 45-47 Ziołowa St, Katowice, Poland, phone: +48 3225239 30, fax: +48 3225239 30, e-mail: tomasz.jadczyk@gmail.com

Received: 5.12.2020, accepted: 23.07.2021. 
Su m mary

Detailed assessment of global unipolar voltage, bipolar voltage and local linear shortening parameters of the left ventricle were $11.56 \mathrm{mV}, 3.63 \mathrm{mV}$ and $11.32 \%$, respectively. Comparing active and placebo groups, there were no significant differences in electromechanical (EM) characteristics at global and segmental levels. Analysis of factors associated with improvement of ischemic segments in single-photon emission computed tomography (SPECT) showed no correlation between EM parameters and changes of perfusion at rest and stress. Baseline SPECT results are only predictors of changes of myocardial ischemia observed at 4-month follow-up. With median value-based grouping, the correlation between EM parameters and myocardial ischemia changes in the active group showed no statistical significance.

\section{Introduction}

The long-term prognosis of patients with both acute coronary syndrome and chronic coronary syndromes has improved due to multi-modal approaches, including interventional and surgical revascularization along with optimal medical treatment $[1,2]$. However, some patients complain of refractory angina (RFA), alternatively defined as no-option angina, which refers to the presence of chest pain symptoms/angina equivalents (lasting for $\geq 3$ months) associated with reversible ischemia due to untreatable obstructive coronary artery disease not amenable to conventional treatment (neither pharmacological nor interventional) [1]. Pre-clinical and phase I/II studies showed that trans-endocardial application of cell therapy might serve as a promising treatment strategy for these patients $[3,4]$. The REGENT-VSEL trial evaluated the effects of trans-endocardial injection of autologous bone marrow-derived CD133+ cells in the left ventricle (LV) of such patients [3]. Despite a lack of significant difference in inducible ischemia between the treatment and placebo group after 4 months, the logistic regression model suggested that allocation to the stem cell arm was associated with $3.5 \times$ higher odds of SPECT-evaluated reduction of ischemic area [3]. Thus, to further evaluate potential stem cell-induced changes of myocardial ischemia, we performed an in-depth analysis of electromechanical parameters and their correlation with SPECT results. Importantly, data from the 3-dimensional NOGA XP mapping system [5] allows for detailed electromechanical analysis and delineation of hibernated - i.e., viable but hypokinetic - myocardium.

\section{Aim}

Taking into consideration novel insights and advances in the field, we aim to perform a retrospective analysis of the REGENT-VSEL trial (1) analyzing EM parameters (unipolar voltage (UV), bipolar voltage (BV), and local linear shortening (LLS)) of LV in patients with RFA, and (2) assessing the correlation between EM characteristics and changes in myocardial ischemia.

\section{Material and methods}

\section{Study population}

Thirty of 31 patients from the REGENT-VSEL [3] trial were enrolled in the retrospective analysis. The placebo and active group consisted of 14 and 16 patients, respectively. One patient from the placebo group was excluded because of a missing electromechanical map.

\section{Inclusion criteria}

1) Stable angina in CCS class II-IV despite maximum pharmacotherapy for at least 2 weeks since last change of medications; 2) presence of $\geq 1$ myocardial segment with reversible ischemia in qualifying Tc-99m SPECT; 3) disqualified from further revascularization by independent Heart Team; 4) age > 18 and < 75 years; and 5) written informed consent.

\section{Exclusion criteria}

1) acute coronary syndrome $\leq 6$ months; 2) heart failure NYHA class III-IV; 3) LVEF < 35\%; 4) contraindications to NOGA procedure (ventricular wall thickness $<8 \mathrm{~mm}$, intracardiac thrombus, severe aortic stenosis, LV an aneurysm or severe peripheral artery disease precluding the vascular access); 5) previous implantation of cardioverter-defibrillator or pacemaker; 6) history of malignancy; 7) active infection; 8) life expectancy less than 6 months; 9) bleeding diathesis; 10) renal insufficiency (GFR $<30 \mathrm{ml} / \mathrm{min} / 1.73 \mathrm{~m}^{2}$ ) and 11) pregnancy, lactation, or lack of effective contraception in women of childbearing potential.

\section{Single-photon emission tomography}

All patients underwent a myocardial perfusion gated SPECT study, using the 1-day protocol with the adenosine stress test. The adenosine stress test was performed first, during which patients received adenosine infusion intravenously at the rate of $140 \mu \mathrm{g} / \mathrm{kg} / \mathrm{min}$ for $6 \mathrm{~min}$. At the third minute of infusion approx. $370 \mathrm{MBq}$ of $99 \mathrm{mTC}-\mathrm{MIBI}$ was administered intravenously with continuous electrocardiographic and blood pressure monitoring. A similar dose of $99 \mathrm{mTC}-\mathrm{MIBI}$ was administered intravenously $6 \mathrm{~h}$ later for the resting myocardial perfusion. The $99 \mathrm{mTC}-\mathrm{MIBI}$ gated SPECT study was done approx. 45 min after the administration of $99 \mathrm{mTC}-\mathrm{MIBI}$ for both the adenosine stress and rest studies. Acquisition used a low-energy, high-resolution (LEHR) collimator, 180-degree acquisition over 64 projections, $25 \mathrm{~s}$ per projection with patients in the supine position and a $15 \%$ window centered on the $140 \mathrm{KeV}$ peak in a Siemens dual-head- 
ed gamma camera (Symbia, Siemens Healthcare). Preprocessing was done with a Butterworth filter of order 5 with a cutoff frequency of $0.33 \mathrm{~Hz}$. Short axis, vertical and horizontal long axes tomograms of the LV were automatically extracted from the reconstructed trans-axial tomograms by performing reorientation to the long axis of the LV. Perfusion defect score was evaluated by the severity of perfusion of each segment scale from 0 (normal uptake) to 4 (uptake absent) using the visual analysis of results obtained using QPS software (Cedars-Sinai, Los Angeles, California). The summed stress scores (SSS) equaled the sum of the stress scores of all the segments, and the summed rest score (SRS) equaled the sum of the resting scores of all the segments. The difference between the SSS and SRS is the summed difference score (SDS), and it was a measure of inducible ischemia [6]. In order to match the NOGA-XP system, semi-quantitative analysis was performed using a matching 9-segment scoring model calculating the percentage of myocardial ischemia ranging from $0 \%$ to $100 \%$.

\section{Electromechanical mapping and stem cell injection}

Patients underwent electromechanical mapping and the intramyocardial cell/placebo application procedure with the NOGA-XP 3D system (Biosense Webster, Johnson \& Johnson, Diamond Bar, CA, USA). During the procedure, approximately 200-250 mapping points were collected in order to obtain a precise electromechanical map of the left ventricle. Target regions of the myocardium with impaired mechanical (LLS (reflecting regional wall motion) $<6 \%$ ) but maintained electrical activity of $\geq 6.0 \mathrm{mV}$ UV were defined as a viable hibernated myocardium. Thereafter, a median of 10 intramyocardial CD133+ cells (dosing ranges $2.8 \times 10^{6}-5.3 \times 10^{6}$ )/placebo injections were performed using a MyoStar catheter (Biosense Webster, Johnson \& Johnson, Diamond Bar, CA, USA).

\section{Post-processing of electromechanical data}

A nine-segment model of the LV (bulls-eye projection, Figure 1) was used to position NOGA-XP mapping points. Each of the LV segments (basoseptal, basolateral, posterobasal, anterobasal, midseptal, midlateral, midposterior, midanterior and apical) was represented by an averaged value of UV, BV, LLS parameters. Subsequently, corresponding global EM parameters were calculated as a mean or median value of all 9 segments for UV, BV and LLS.

\section{Statistical analysis}

Data are shown as mean \pm standard deviation (SD) or median $\left(25^{\text {th }} ; 75^{\text {th }}\right.$ percentile) for quantitative data or number and percentage for qualitative data. The prevalence of features in the subgroups was compared with the $\chi^{2}$ test. The differences between groups were analyzed by the Mann-Whitney U-test or Student's $t$-test used as appropriate according to normality of variables tested by the Shapiro-Wilk test. The relative difference (RD) of rest and stress myocardial ischemia at baseline (pre-injection) and 4-month follow-up (post-injection) was calculated based on SPECT examination according to the following formula: RD = (ischemia at baseline (\%) ischemia at follow-up (\%))/ischemia at baseline (\%).

Positive and negative RD values refer to increase and decrease of myocardial ischemia (\%), respectively.

Since the EM variables representing global and segmental characteristics were not normally distributed, patients were grouped based on the median value of each parameter. Multiple linear regression was firstly employed to test the correlation between post-injection SPECTs as dependent variables and pre-injection SPECT+ EM parameters as independent ones. Subsequently, simple linear regression was used to assess individual associations between stress and rest SPECT variability and different levels of UV, BV, and LLS variables, including consideration of intervention (CD133+ cells). Missing data were excluded from all analyses, and the level of significance was set at $p<0.05$. Analyses were performed with TIBCO Software Inc. (2017) Palo Alto, USA. Statistica (data analysis software), SAS 9.4 (SAS Institute Inc., Cary, NC, USA) and Prism 9 (GraphPad, San Diego, CA, USA).

\section{Results}

Electromechanical and perfusion characteristics

Global electromechanical and SPECT-evaluated perfusion characteristics of LV are presented in Table I. We found no significant differences in global UV, BV, and LLS as well as rest and stress SPECT values between active and placebo groups.

Segmental electromechanical data are presented in Table II. There are no significant differences between cell and control groups regarding EM parameters at the segmental level.

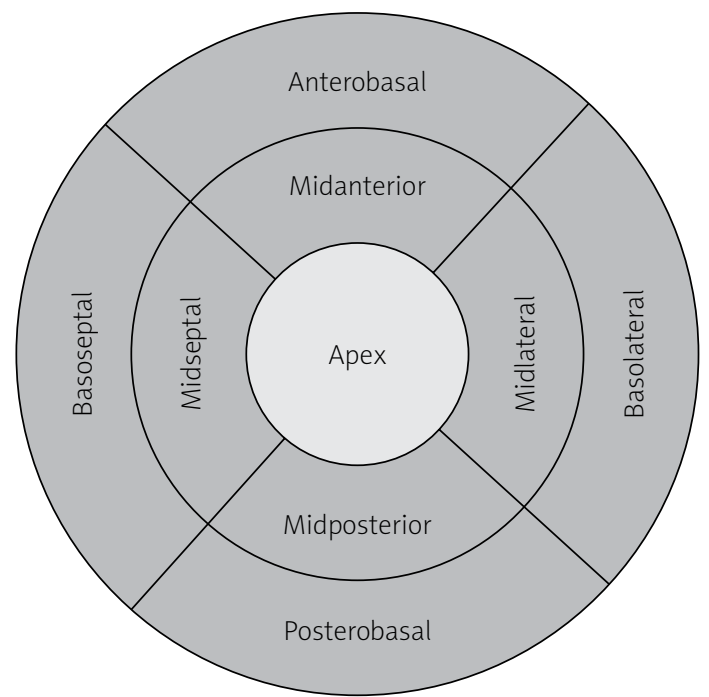

Figure 1. Nine-segment model of the left ventricle 
Table I. Left ventricle electromechanical and perfusion characteristics

\begin{tabular}{lccccc} 
Variable & $\begin{array}{c}\text { Global LV unipolar } \\
\text { voltage [mV] }\end{array}$ & $\begin{array}{c}\text { Global LV bipolar } \\
\text { voltage [mV] }\end{array}$ & $\begin{array}{c}\text { Global LV local linear } \\
\text { shortening (\%) }\end{array}$ & $\begin{array}{c}\text { Baseline LV rest } \\
\text { SPECT (\%) }\end{array}$ & $\begin{array}{c}\text { Baseline LV stress } \\
\text { SPECT (\%) }\end{array}$ \\
\hline Active group & $11.28(10.46-12.29)$ & $3.58(3.27-3.87)$ & $11.12(9.63-13.42)$ & $59(13.5-142)$ & $89.5(12.5-212.5)$ \\
\hline Placebo group & $13.00(11.18-17.07)$ & $3.81(3.01-4.30)$ & $11.32(9.72-11.78)$ & $72(15-59)$ & $107.5(52-140)$ \\
\hline Intergroup $p$-value & 0.09 & 0.72 & 0.69 & 0.5 & 0.6 \\
\hline Total population & $11.56(10.94-14.45)$ & $3.63(3.04-4.17)$ & $11.06(9.72-13.25)$ & $33(15-123)$ & $98(49-189)$
\end{tabular}

Data presented as median $\left(25^{\text {th }}-75^{\text {th }}\right)$; LLS - local linear shortening, LV - left ventricle.

Table II. Segmental electromechanical characteristics

\begin{tabular}{lccccccccc} 
Segments & \multicolumn{3}{c}{ Active group } & \multicolumn{3}{c}{ Control group } \\
\cline { 2 - 9 } & (1) UV [mV] & (2) BV [mV] & (3) LLS (\%) & (4) UV [mV] & (5) BV [mV] & (6) LLS (\%) & $\mathbf{1}$ vs. 4 & 2 vs. 5 & 3 vs. 6 \\
\hline Anterobasal & $16.88 \pm 6.87$ & $3.10 \pm 1.24$ & $10.55 \pm 9.17$ & $9.61 \pm 1.70$ & $2.63 \pm 1.19$ & $-0.03 \pm 2.72$ & 0.4 & 0.4 & 0.2 \\
\hline Basoseptal & $8.62 \pm 3.83$ & $2.85 \pm 1.96$ & $9.57 \pm 5.81$ & $8.93 \pm 3.87$ & $3.00 \pm 1.95$ & $7.93 \pm 6.03$ & 0.9 & 0.9 & 0.4 \\
\hline Posterobasal & $9.01 \pm 2.81$ & $3.53 \pm 1.61$ & $9.45 \pm 3.47$ & $11.78 \pm 3.50$ & $4.65 \pm 1.69$ & $6.55 \pm 5.30$ & 0.1 & 0.2 & 0.3 \\
\hline Basolateral & $15.47 \pm 6.91$ & $4.31 \pm 1.97$ & $7.30 \pm 5.02$ & $12.68 \pm 3.73$ & $4.80 \pm 1.58$ & $11.80 \pm 11.37$ & 0.7 & 0.6 & 0.7 \\
\hline Midanterior & $16.80 \pm 6.91$ & $4.16 \pm 2.63$ & $11.98 \pm 3.18$ & $14.13 \pm 4.05$ & $3.85 \pm 2.40$ & $10.55 \pm 6.06$ & 0.6 & 0.5 & 0.6 \\
\hline Midseptal & $11.68 \pm 2.44$ & $2.75 \pm 1.62$ & $9.66 \pm 5.62$ & $15.82 \pm 6.08$ & $4.06 \pm 0.84$ & $10.34 \pm 4.39$ & 0.1 & 0.09 & 0.7 \\
\hline Midposterior & $13.58 \pm 2.74$ & $4.55 \pm 0.86$ & $9.82 \pm 5.97$ & $14.26 \pm 5.72$ & $5.37 \pm 2.09$ & $9.13 \pm 2.46$ & 0.9 & 0.4 & 0.4 \\
\hline Midlateral & $15.07 \pm 4.29$ & $3.31 \pm 1.01$ & $12.17 \pm 5.10$ & $14.92 \pm 4.70$ & $3.46 \pm 0.68$ & $8.22 \pm 4.26$ & 0.8 & 0.5 & 0.1 \\
\hline Apex & $12.9 \pm \mathrm{n} / \mathrm{a}$ & $4.1 \pm \mathrm{n} / \mathrm{a}$ & $20.4 \pm \mathrm{n} / \mathrm{a}$ & $14.20 \pm 7.63$ & $2.15 \pm 0.21$ & $16.7 \pm 9.33$ & $\mathrm{n} / \mathrm{a}$ & $\mathrm{n} / \mathrm{a}$ & $\mathrm{n} / \mathrm{a}$
\end{tabular}

Data presented as mean \pm SD. UV - unipolar voltage, BV-bipolar voltage, LLS - local linear shortening, n/a - not available, UV - unipolar voltage.

\section{Correlative results between treatment groups}

Global changes of myocardial ischemia expressed as $\mathrm{RD}$ and EM parameters showed none or weak correlation for UV, BV and LLS at rest $(R=-0.06 ; R=0.2 ; R=$ -0.1 , respectively), see Figures 2 A-C. Results of correlation analysis using RD at stress did not im-prove $R$ values ( $R=0.07 ; R=0.09 ; R=-0.1$, respectively), Figures $2 \mathrm{D}-\mathrm{F}$. Similar analysis performed in patients who received CD133+ cell therapy showed none or a weak cor-relation in SPECT at rest for UV $(R=-0.2)$, BV $(R=0.03)$ and LLS $(R=-0.4)$, see Figures $3 \mathrm{~A}-\mathrm{C}$. No or weak cor-relation was found in SPECT at stress $(R=0.02 ; R=0.2 ; R=-0.2$, respectively), see Figures $3 \mathrm{D}-\mathrm{F}$.

Multiple linear regression of the treated segments showed that only pre-injection SPECT levels - both at rest and stress - were significantly or close to significance correlated with post-injection SPECT, either at rest ( $p=$ 0.001 vs. pre-injection SPECT levels at rest and $p=0.0003$ vs. pre-injection SPECT levels at stress) and stress ( $p=$ 0.076 vs. pre-injection SPECT levels at rest and $p=0.041$ vs. pre-injection SPECT levels at stress). The pre-injection and post-injection levels showed a positive correlation.

Segmental intragroup correlation between electromechanical parameters and myocardial ischemia based on median value-based grouping

\section{Active group}

Unipolar voltage. With a division criterion of global LV unipolar median value, patients were assigned to Group 1
(<11.56 mV) or Group 2 ( $\geq 11.56 \mathrm{mV}$ ). Unipolar voltage did not correlate with response to cell therapy reflected by changes of myocardial ischemia analyzed by rest and stress SPECT test (Table III).

Bipolar voltage. With a division criterion of global LV bipolar median value, patients were assigned to Group 1 $(<3.63 \mathrm{mV}$ ) or Group 2 ( $\geq 3.63 \mathrm{mV})$. Bipolar voltage did not correlate with response to cell therapy reflected by changes of myocardial ischemia analyzed by rest and stress SPECT test (Table IV).

Local linear shortening. With a division criterion of global LV LLS median value, patients were assigned to Group 1 (< 11.5$)$ or Group 2 ( $\geq 11.5)$. LLS did not correlate with response to cell therapy reflected by changes of myocardial ischemia analyzed by rest and stress SPECT test (Table V).

\section{Placebo group}

A similar analysis was conducted for the placebo group. The results correspond with the active group and show no significant differences.

Global intergroup and intragroup correlation between electromechanical parameters and myocardial ischemia based on median value-based grouping

No statistically significant differences in myocardial ischemia changes were observed within the active and placebo group (intragroup analysis) or between groups 
A

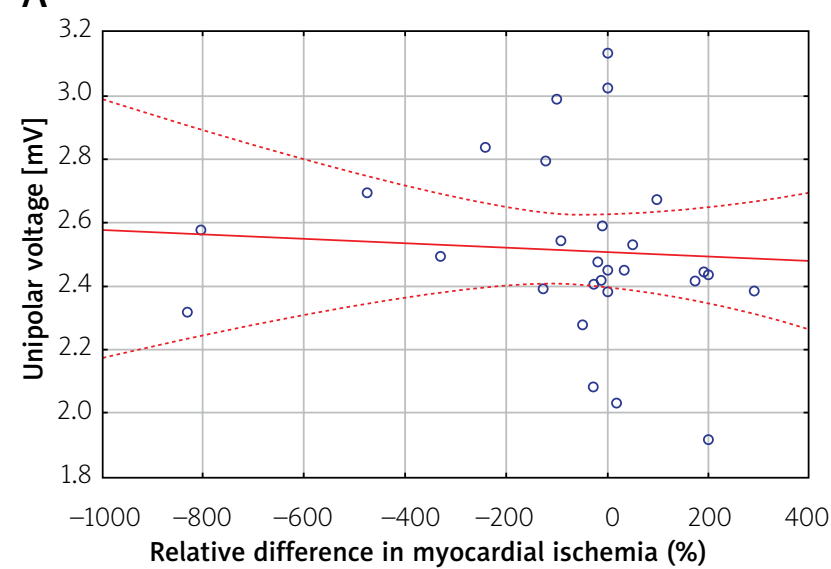

B

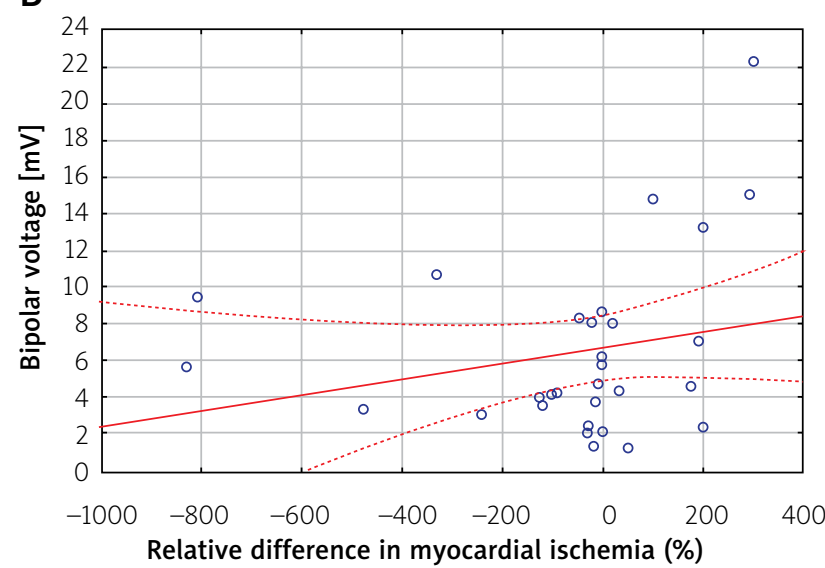

C

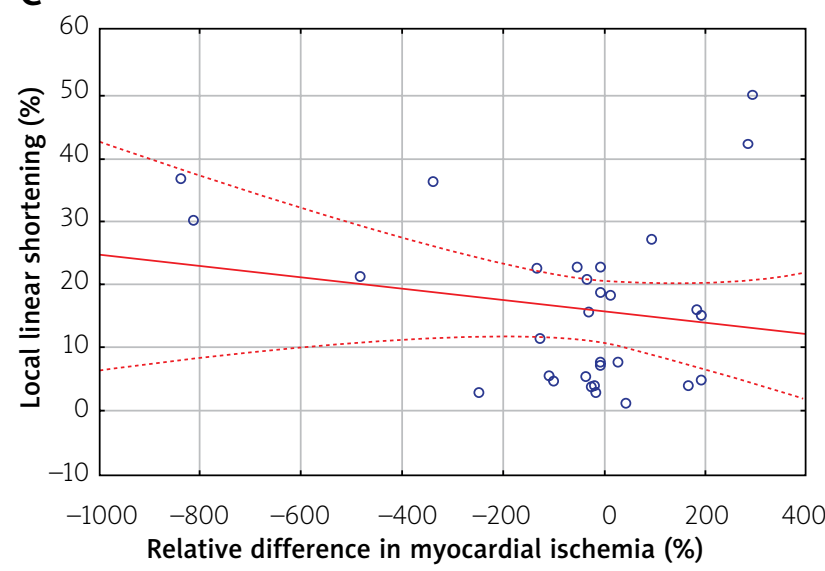

D

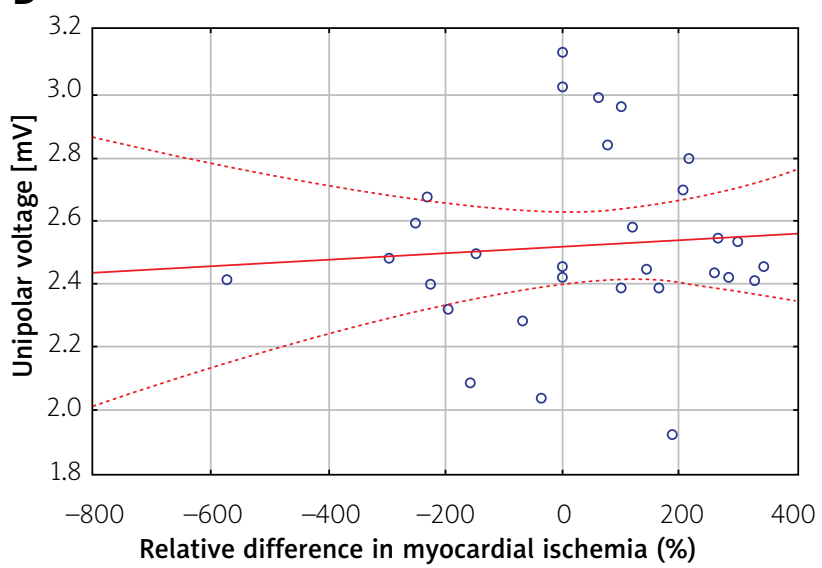

$\mathrm{E}$



$\mathrm{F}$

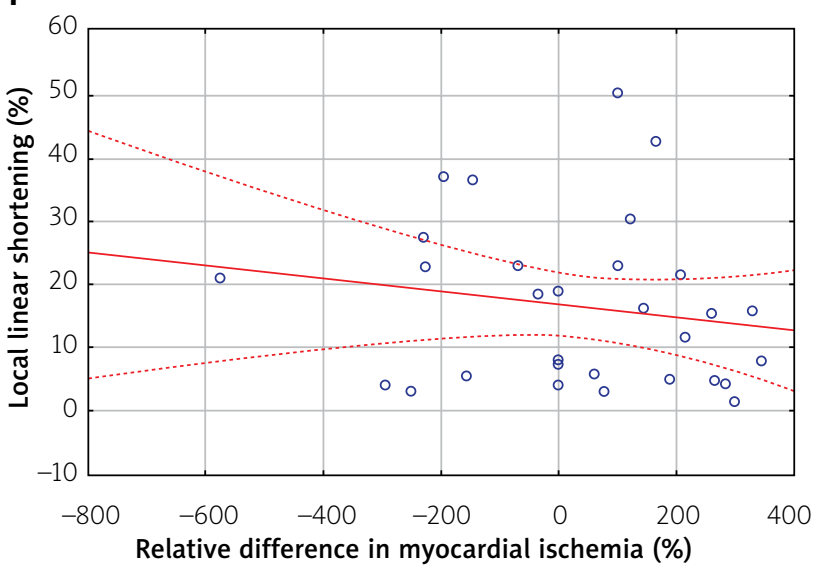

Figure 2. Correlation between median value of the left ventricle EM parameters (unipolar voltage, bipolar voltage, local linear shortening) and global changes of SPECT-evaluated myocardial ischemia at rest $(\mathbf{A}-\mathbf{C})$ and stress (D-F)

(intergroup analysis) using the median value of each EM parameter for grouping (Table VI).

\section{Discussion}

In order to evaluate new factors that might be associated with changes of myocardial ischemia upon CD133+ cell injection, we integrated SPECT data with electrome- chanical maps acquired from NOGA XP, obtaining a unique insight into mutual relations between EM parameters and ischemic substrates. Regardless of overall electromechanical characteristics of LV as well as cell-targeted segments, time-dependent changes of myocardial ischemia do not appear to be related to the CD133+ treatment or presented EM characteristics. The primary findings of this retro- 
A

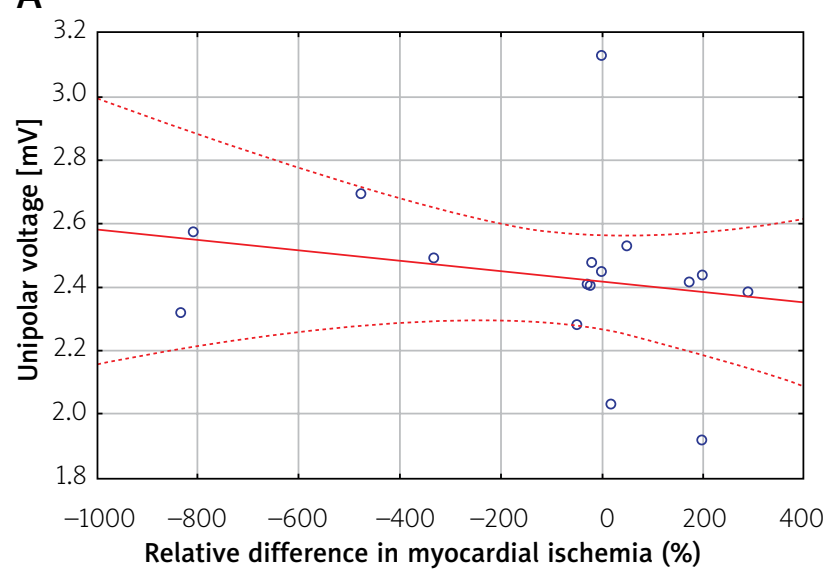

B

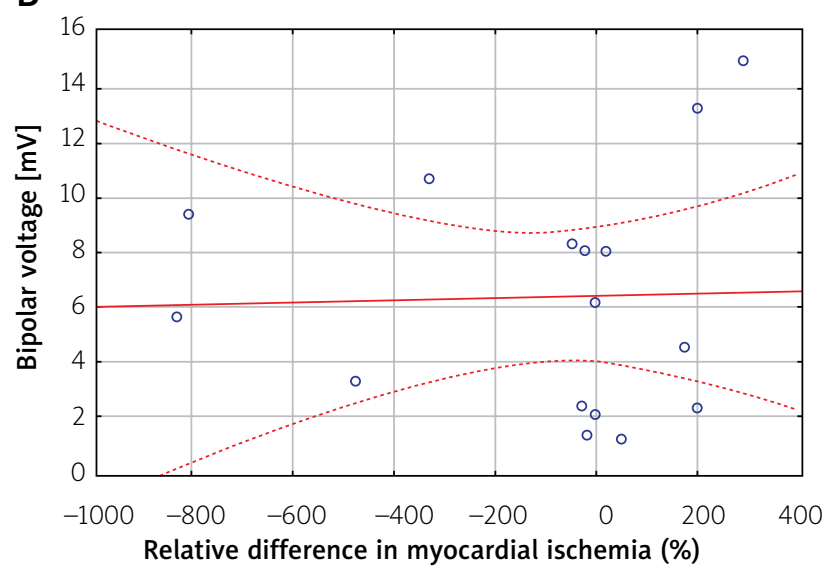

C

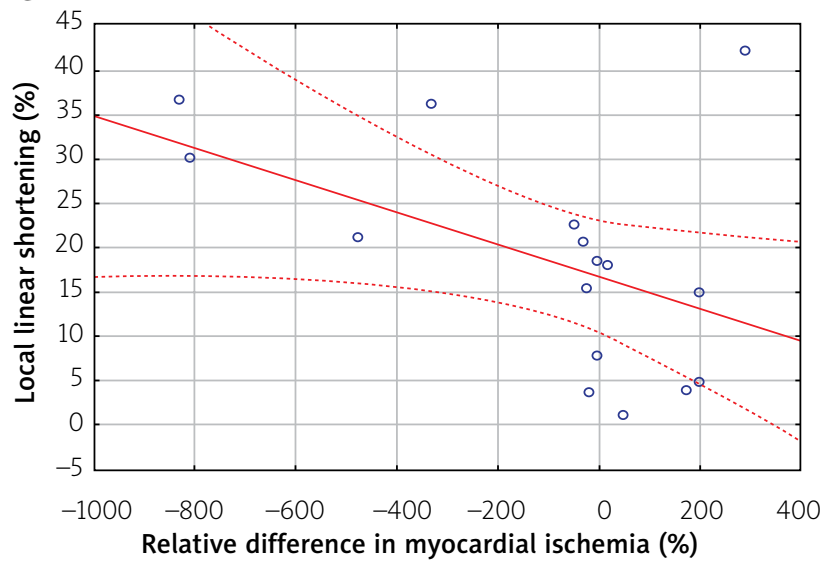

D STRESS SPECT

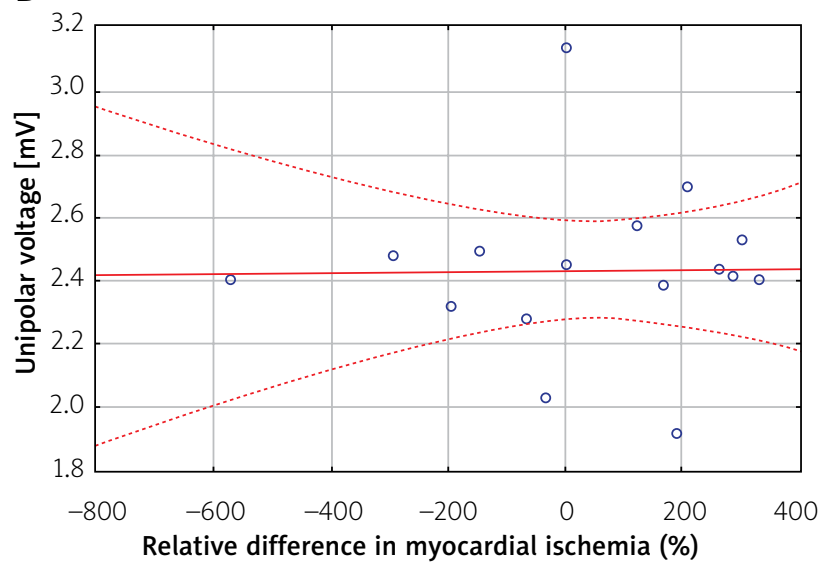

E

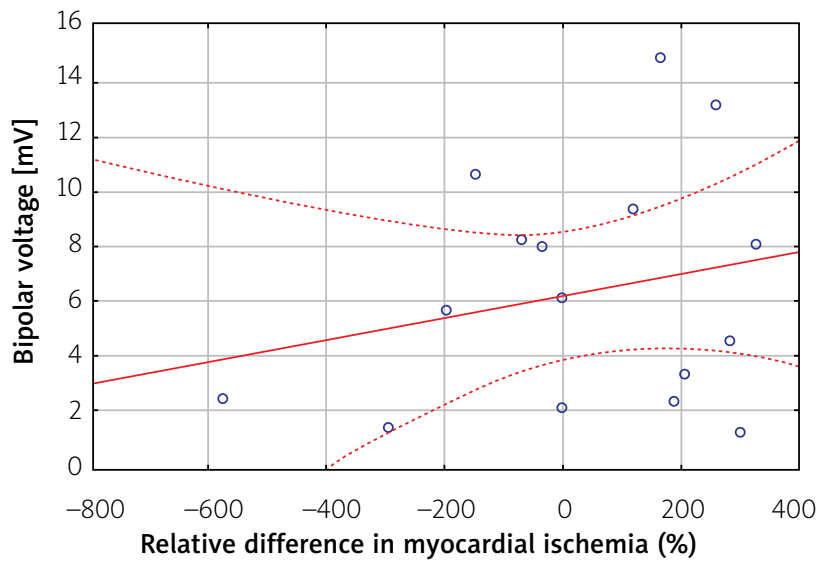

F



Figure 3. Correlation between median of the left ventricle EM parameters (unipolar voltage, bipolar voltage, local linear shortening) values of hibernated segments injected with CD133+ cells and changes of SPECT-evaluated myocardial ischemia of targeted segments at rest $(\mathbf{A}-\mathbf{C})$ and stress $(\mathbf{D}-\mathbf{F})$

spective study demonstrate that patients with RFA have comparable EM properties of LV myocardium and that intramyocardial CD133+ cell therapy was not associated with the reduction of ischemia measured in SPECT, which is in line with the primary results of the REGENT-VSEL trial.

Results of the stem cell therapy applying transendocardial delivery should be interpreted in regard to the EM parameters of the scar, target zone, and viable myocardium. EM characteristics of left ventricle myocardium described in our retrospective analysis are in line with data from the PROGENITOR study applying CD133+ cells in the RFA population, where the authors reported global UV values in the active and control group as 10.4 (7.4 to 14.2 ) and 12.5 (8.1 to 15.0$) \mathrm{mV}$, respectively. Furthermore, 
Table III. Correlation between unipolar voltage and changes of myocardial ischemia

\begin{tabular}{|c|c|c|c|c|c|c|}
\hline \multirow[t]{2}{*}{ Segment } & \multicolumn{2}{|c|}{ Rest SPECT } & \multirow{2}{*}{$\begin{array}{l}\text { Intragroup } \\
p \text {-value }\end{array}$} & \multicolumn{2}{|c|}{ Stress SPECT } & \multirow{2}{*}{$\begin{array}{c}\text { Intragroup } \\
p \text {-value }\end{array}$} \\
\hline & $\begin{array}{c}\text { Group } 1 \\
\text { (UV }<11.55 \mathrm{mV} \text { ) } \\
\text { RD of myocardial } \\
\text { ischemia (\%) }\end{array}$ & $\begin{array}{c}\text { Group } 2 \\
\text { (UV } \geq 11.55 \mathrm{mV} \text { ) } \\
\text { RD of myocardial } \\
\text { ischemia (\%) }\end{array}$ & & $\begin{array}{c}\text { Group } 1 \\
\text { (UV < } 11.55 \mathrm{mV} \text { ) } \\
\text { RD of myocardial } \\
\text { ischemia (\%) }\end{array}$ & $\begin{array}{c}\text { Group } 2 \\
\text { (UV } \geq 11.55 \mathrm{mV}) \\
\text { RD of myocardial } \\
\text { ischemia (\%) }\end{array}$ & \\
\hline Anterobasal & No data & 100 & & 42.85 & $95.29 \pm 10.52$ & 0.5 \\
\hline Basoseptal & No data & 100 & & No data & $88.33 \pm 20.20$ & \\
\hline Posterobasal & $-199.28 \pm 420.45$ & $-78.41 \pm 288.33$ & 0.5 & $-16.78 \pm 94.03$ & $45.59 \pm 74.83$ & 0.1 \\
\hline Basolateral & $51.45 \pm 45.92$ & $-81.36 \pm 114.78$ & 0.02 & $-44.40 \pm 232.91$ & $-17.41 \pm 97.85$ & 0.8 \\
\hline Midanterior & $11.57 \pm 78.14$ & $-60.58 \pm 154.10$ & 0.2 & $9.33 \pm 13.43$ & $-13.70 \pm 127.11$ & 0.2 \\
\hline Midseptal & $37.07 \pm 57.22$ & $2.70 \pm 126.12$ & 0.9 & $9.58 \pm 63.77$ & $-24.47 \pm 66.27$ & 0.01 \\
\hline Midposterior & $-36.34 \pm 125.11$ & $-3.20 \pm 14.63$ & 0.8 & $24.49 \pm 107.46$ & $13.35 \pm 54.69$ & 0.5 \\
\hline Midlateral & $38.57 \pm 62.10$ & $-80.14 \pm 234.70$ & 0.2 & $19.12 \pm 82.27$ & $44.98 \pm 54.07$ & 0.8 \\
\hline Apex & $2.92 \pm 80.06$ & $10.04 \pm 65.19$ & 0.2 & $45.42 \pm 41.20$ & $-1.53 \pm 73.47$ & 0.1 \\
\hline
\end{tabular}

Data presented as mean $\pm S D$. UV - unipolar voltage, $R D$ - relative difference.

Table IV. Correlation between bipolar voltage and changes of myocardial ischemia

\begin{tabular}{|c|c|c|c|c|c|c|}
\hline \multirow[t]{2}{*}{ Segment } & \multicolumn{2}{|c|}{ Rest SPECT } & \multirow{2}{*}{$\begin{array}{c}\text { Intragroup } \\
p \text {-value }\end{array}$} & \multicolumn{2}{|c|}{ Stress SPECT } & \multirow{2}{*}{$\begin{array}{c}\text { Intragroup } \\
p \text {-value }\end{array}$} \\
\hline & $\begin{array}{c}\text { Group } 1 \\
\text { (BV }<3.62 \mathrm{mV} \text { ) } \\
\text { RD of myocardial } \\
\text { ischemia }(\%)\end{array}$ & $\begin{array}{c}\text { Group } 2 \\
\text { (BV } \geq 3.62 \mathrm{mV} \text { ) } \\
\mathrm{RD} \text { of myocardial } \\
\text { ischemia (\%) }\end{array}$ & & $\begin{array}{c}\text { Group } 1 \\
\text { (BV }<3.62 \mathrm{mV} \text { ) } \\
\text { RD of myocardial } \\
\text { ischemia (\%) }\end{array}$ & $\begin{array}{c}\text { Group } 2 \\
\text { (BV } \geq 3.62 \mathrm{mV} \text { ) } \\
\text { RD of myocardial } \\
\text { ischemia (\%) }\end{array}$ & \\
\hline Anterobasal & No data & $100.00 \pm n / a$ & 0.99 & $80.95 \pm 32.99$ & $92.15 \pm 13.58$ & 1 \\
\hline Basoseptal & $100.0 \pm n / a$ & $100.00 \pm n / a$ & 1.0 & No data & $88.33 \pm 20.20$ & 1 \\
\hline Posterobasal & $-157.96 \pm 375.66$ & $-99.83 \pm 328.31$ & 0.6 & $-0.20 \pm 92.40$ & $42.09 \pm 79.39$ & 0.7 \\
\hline Basolateral & $43.35 \pm 49.60$ & $-73.26 \pm 123.48$ & 0.6 & $-89.50 \pm 244.81$ & $29.94 \pm 35.42$ & 0,7 \\
\hline Midanterior & $5.64 \pm 57.12$ & $-105.81 \pm 199.59$ & 0.2 & $24.31 \pm 53.01$ & $-131.19 \pm 200.16$ & 0.7 \\
\hline Midseptal & $40.35 \pm 40.84$ & $-11.49 \pm 145.93$ & 0.9 & $7.41 \pm 60.97$ & $-64.10 \pm 46.48$ & 0.3 \\
\hline Midposterior & $-19.64 \pm 25.24$ & $-30.95 \pm 153.58$ & 0.1 & $19.90 \pm 77.77$ & $19.79 \pm 101.37$ & 0.2 \\
\hline Midlateral & $-10.59 \pm 68.90$ & $-19.73 \pm 215.42$ & 0.6 & $34.93 \pm 55.96$ & $28.06 \pm 83.17$ & 0.9 \\
\hline Apex & $23.95 \pm 66.85$ & $-31.90 \pm 60.15$ & 0.5 & $0.66 \pm 63.99$ & $-36.39 \pm 38.94$ & 0.7 \\
\hline
\end{tabular}

Data presented as mean $\pm S D$. BV - bipolar voltage, $n / a-$ not available, $R D$-relative difference.

Table V. Correlation between local linear shortening and changes of myocardial ischemia

\begin{tabular}{|c|c|c|c|c|c|c|}
\hline \multirow[t]{2}{*}{ Segment } & \multicolumn{2}{|c|}{ Rest SPECT } & \multirow{2}{*}{$\begin{array}{l}\text { Intragroup } \\
p \text {-value }\end{array}$} & \multicolumn{2}{|c|}{ Stress SPECT } & \multirow{2}{*}{$\begin{array}{c}\text { Intragroup } \\
p \text {-value }\end{array}$} \\
\hline & $\begin{array}{c}\text { Group } 1 \\
\text { (LLS }<11.05 \%) \\
\text { RD of myocardial } \\
\text { ischemia (\%) }\end{array}$ & $\begin{array}{c}\text { Group } 2 \\
\text { (LLS } \geq 11.05 \%) \\
\text { RD of myocardial } \\
\text { ischemia (\%) }\end{array}$ & & $\begin{array}{c}\text { Group } 1 \\
\text { (LLS }<11.05 \% \text { ) } \\
\text { RD of myocardial } \\
\text { ischemia (\%) }\end{array}$ & $\begin{array}{c}\text { Group } 2 \\
\text { (LLS } \geq 11.05 \%) \\
\text { RD of myocardial } \\
\text { ischemia (\%) }\end{array}$ & \\
\hline Anterobasal & 100.00 & 100.0 & & 100.00 & 79.83 & \\
\hline Basoseptal & 100.00 & 100.0 & 0.5 & 100.00 & 65.00 & \\
\hline Posterobasal & $-78.91 \pm 288.52$ & $-198.66 \pm 420.52$ & 1 & $45.55 \pm 67.79$ & $-16.74 \pm 67.79$ & 1 \\
\hline Basolateral & $-50.97 \pm 136.54$ & $21.06 \pm 64.11$ & 0.6 & $-88.51 \pm 255.52$ & $15.79 \pm 255.52$ & 0.8 \\
\hline Midanterior & $-98.21 \pm 244.49$ & $-13.53 \pm 71.91$ & 0.2 & $-21.88 \pm 152.96$ & $8.31 \pm 152.96$ & 0.6 \\
\hline Midseptal & $44.31 \pm 81.51$ & $-6.34 \pm 125.17$ & 0.6 & $-0.36 \pm 59.69$ & $-21.86 \pm 59.69$ & 0.7 \\
\hline Midposterior & $-47.36 \pm n / a$ & $-20.88 \pm 109.61$ & 0.5 & $33.70 \pm 56.15$ & $9.95 \pm 56.15$ & 0.5 \\
\hline Midlateral & $25.11 \pm 84.58$ & $-51.65 \pm 219.57$ & 0.9 & $46.39 \pm 50.58$ & $17.87 \pm 50.58$ & 0.8 \\
\hline Apex & $17.00 \pm 74.01$ & $0.66 \pm 68.60$ & 0.5 & $40.80 \pm 60.57$ & $-18.08 \pm 60.57$ & 0.9 \\
\hline
\end{tabular}

Data presented as mean $\pm S D$. LLS - local linear shortening, n/a-not available, RD - relative difference. 
Table VI. Intergroup comparison of electromechanical parameters

\begin{tabular}{|c|c|c|c|c|c|c|c|}
\hline \multirow[t]{2}{*}{ Variable } & & \multicolumn{2}{|c|}{ Stress SPECT } & \multirow{2}{*}{$\begin{array}{c}\text { Intergroup } \\
p \text {-value }\end{array}$} & \multicolumn{2}{|c|}{ Rest SPECT } & \multirow{2}{*}{$\begin{array}{c}\text { Intergroup } \\
p \text {-value }\end{array}$} \\
\hline & & Active group & Placebo group & & Active group & Placebo group & \\
\hline \multirow{9}{*}{$\begin{array}{l}\text { RD of myocar- } \\
\text { dial ischemia } \\
\text { (\%) }\end{array}$} & $\mathrm{UV}<11.55 \mathrm{mV}$ & $39.40 \pm 290.72$ & $-70.42 \pm 147.64$ & 0.7 & $-4.25 \pm 332.78$ & $-41.94 \pm 57.35$ & 0.6 \\
\hline & $\mathrm{UV} \geq 11.55 \mathrm{mV}$ & $26.74 \pm 204.13$ & $72.79 \pm 193.85$ & 0.8 & $-224.92 \pm 323.53$ & $6.47 \pm 159.00$ & 0.7 \\
\hline & $\begin{array}{c}\text { Intragroup } \\
p \text {-value }\end{array}$ & 0.8 & $>0.99$ & & 0.9 & 0.5 & \\
\hline & $\mathrm{BV}<3.62 \mathrm{mV}$ & $-14.32 \pm 319.10$ & $74.68 \pm 233.74$ & 0.7 & $-41.73 \pm 95.19$ & $15.93 \pm 95.19$ & 0.6 \\
\hline & $\mathrm{BV} \geq 3.62 \mathrm{mV}$ & $82.05 \pm 158.96$ & $-0.23 \pm 155.74$ & 0.9 & $-159.86 \pm 348.00$ & $-24.83 \pm 166.08$ & 0.7 \\
\hline & $\begin{array}{c}\text { Intragroup } \\
p \text {-value }\end{array}$ & 0.5 & 0.4 & & 0.1 & 0.4 & \\
\hline & LLS < $11.05 \%$ & $7.04 \pm 271.76$ & $74.11 \pm 221.21$ & 0.6 & $-77.30 \pm 345.44$ & $10.28 \pm 137.92$ & 0.7 \\
\hline & LLS $\geq 11.05 \%$ & $60.67 \pm 238.54$ & $-10.36 \pm 154.71$ & 0.7 & $-124.30 \pm 350.83$ & $-25.00 \pm 144.68$ & 0.3 \\
\hline & $\begin{array}{c}\text { Intragroup } \\
p \text {-value }\end{array}$ & 0.3 & 0.7 & & 0.1 & 0.09 & \\
\hline
\end{tabular}

Data presented as mean \pm SD. UV - unipolar voltage, BV - bipolar voltage, LLS - local linear shortening, RD - Relative difference, UV - unipolar voltage.

overall LLS values were 10.6 (5.2 to 13.6$)$ and 10.7 (3.8 to 17.4$)$, respectively. To personalize treatment strategy and select targeted regions, it is necessary to delineate hibernated myocardium, defined as viable tissue devoid of or with significantly reduced contractile function, as well as fibrotic scar tissue regions characterized by low UV and LLS reflecting no electrical or mechanical activity. Importantly, the definition of myocardial properties for the most suitable injection site is still under scientific debate, mirroring inconsistent results of stem cell trials [4, $7,8]$. Moreover, recent trials change perspective in terms of different cut-off values for unipolar and bipolar voltage of hibernated myocardium, which can significantly affect the cell therapy response $[9,10]$. In our study, CD133+ cells were injected in the areas with UV $\geq 6.0 \mathrm{mV}$ (with the exception of 2 out of 315 cell injections, when cells were injected in the areas of UV $<6.0 \mathrm{mV}$ ) and LLS $<6 \%$. In comparison to the REGENT-VSEL trial, the PROGENITOR study used $6.9 \mathrm{mV}$ UV and LLS < $12 \%$ cut-offs for hibernated myocardium showing improvement of the SPECT-derived summed score at rest and stress in the active group (median absolute difference -1.0 (95\% Cl: -1.9 to -0.1)). Interestingly, in the active group within 6-month follow-up, LLS value improved statistically from 10.6 to 12.3 ( $p=0.01$ ), while in the placebo group LLS was reduced from 10.7 to $8.9(p=0.30)$. These data suggest that baseline EM parameters of the cell target zone may play a role. Moreover, it is proposed not only to change the cut-off values of viable myocardium to UV $6.7 \mathrm{mV}$ and BV $3.0 \mathrm{mV}$, but also to take into consideration the presence of LV remodeling with further voltage changes [9].

In contrast to our results, electro-anatomical properties of myocardium were found to predict response to stem cell therapy. In the study by Zemljic et al. [11], patients with ischemic and non-ischemic heart failure received $\mathrm{CD} 34+$ stem cell injections into hibernated myocardial segments. The authors defined hibernated myocardium as areas with unipolar voltage $\geq 8.3 \mathrm{mV}$ and myocardial scar as segments with unipolar voltage of < $8.3 \mathrm{mV}$. In conclusion, higher myocardial scar burden was associated with worse clinical response to CD34+ cell therapy. It is worth remarking that CD133+ cells are a subfraction of CD34+ coexpressing this surface marker [12]. Presented data suggest that the clinical effect of cell therapy depends on the cell type, underlying medical condition and EM characteristics of target zones.

Heterogeneity of EM parameters values for target zone, scar and viable myocardium hinder comparison of our study results with data from other trials. However, we performed an additional analysis classifying patients into groups based on the median value of each EM parameter to simulate different cut-offs. Due to the relatively small number of patients included in the analysis, further studies with larger numbers of participants are needed.

\section{Conclusions}

Detailed assessment of global UV, BV and LLS parameters of the left ventricle were $11.56 \mathrm{mV}, 3.63 \mathrm{mV}$ and $11.32 \%$, respectively. Comparing active and placebo groups, there were no significant differences in EM characteristics at global and segmental levels. Analysis of factors associated with improvement of ischemic segments in SPECT showed no correlation between EM parameters and changes of perfusion at rest and stress. Baseline SPECT results are only predictors of changes of myocardial ischemia observed at 4-month follow-up. With median value-based grouping, the correlation between EM parameters and myocardial ischemia changes in the active group showed no statistical significance.

\section{Acknowledgments}

The authors acknowledge Hanspeter Fischer (Biologics Delivery Systems, a Johnson \& Johnson company) for 
his contribution to data acquisition and counseling in the data analysis process.

The trial was sponsored by the Medical University of Silesia (statutory funds KNW-1-048/N/9/K) and funded by European Union structural funds (Innovative Economy Operational Program POIG.01.01.02-00-109/09-00), ReGenHeart (NCT03039751) and SCIENCE (NCT02673164) trials.

\section{Conflict of interest}

Dr Wojakowski received a lecture honorarium from Biosense Webster, a Johnson \& Johnson company. The other authors declare no conflict.

\section{References}

1. Knuuti J, Wijns W, Saraste A, et al. 2019 ESC Guidelines for the diagnosis and management of chronic coronary syndromes. Eur Heart J 2020; 41: 407-77.

2. Neumann FJ, Sousa-Uva M, Ahlsson A, et al. 2018 ESC/EACTS Guidelines on myocardial revascularization. Eur Heart J 2019; 40: 87-165.

3. Wojakowski W, Jadczyk T, Michalewska-Włudarczyk A, et al Effects of transendocardial delivery of bone marrow-derived CD133(+) cells on left ventricle perfusion and function in patients with refractory angina: final results of randomized, double-blinded, placebo-controlled REGENT-VSEL trial. Circ Res 2017; 120: 670-80.

4. Jones DA, Weeraman D, Colicchia $M$, et al. The Impact of cell therapy on cardiovascular outcomes in patients with refractory angina. Circ Res 2019; 124: 1786-95.

5. Psaltis PJ, Worthley SG. Endoventricular electromechanical mapping-the diagnostic and therapeutic utility of the NOGA XP Cardiac Navigation System. J Cardiovasc Transl Res 2009; 2: 48-62.

6. Hesse B, Tägil K, Cuocolo A, et al. EANM/ESC procedural guidelines for myocardial perfusion imaging in nuclear cardiology. Eur J Nucl Med Mol Imaging 2005; 32: 855-97.

7. Ratajczak MZ, Bujko K, Wojakowski W. Stem cells and clinical practice: new advances and challenges at the time of emerging problems with induced pluripotent stem cell therapies. Pol Arch Med Wewn 2016; 126: 879-90.

8. Velagapudi P, Turagam M, Kolte D, et al. Intramyocardial autologous CD34+ cell therapy for refractory angina: a meta-analysis of randomized controlled trials. Cardiovasc Revasc Med 2019; 20: $215-9$

9. Sramko M, Abdel-Kafi S, van der Geest RJ, et al. New adjusted cutoffs for "normal" endocardial voltages in patients with post-infarct LV remodeling. JACC Clin Electrophysiol 2019; 5: 1115-26.

10. Park K, Lai D, Handberg EM, et al. Association between high endocardial unipolar voltage and improved left ventricular function in patients with ischemic cardiomyopathy. Tex Heart Inst J 2016; 43: 291-6.

11. Zemljic G, Poglajen G, Sever M, et al. Electroanatomic properties of the myocardium predict response to CD34+ cell therapy in patients with ischemic and nonischemic heart failure. J Card Fail 2017; 23: 153-60.

12. Cimato TR, Conway A, Nichols J, et al. CD133 expression in circulating hematopoietic progenitor cells. Cytometry B Clin Cytom 2019; 96: 39-45. 